\title{
Peran Guru PAI dalam Bimbingan dan Konseling terhadap Perkembangan Akhlak Siswa di SMA X Cimahi
}

\author{
Siti Mariyah Ulfah", Adang M. Tsaury \\ Prodi Pendidikan Agama Islam, Fakultas Tarbiyah dan Keguruan, \\ Universitas Islam Bandung, Indonesia. \\ *mariyahulfah77@gmail.com, adangtsaury@yahoo.com
}

\begin{abstract}
Counseling Guidance is the process of providing assistance through counseling interviews (face to face) by an expert (called a counselor) to individuals who are experiencing problems (called counselees) leading to the resolution of problems faced by counselees. Moral is a trait that is embedded in the soul of every human being that gives rise to various kinds of actions clearly and easily, without the need for thought and consideration. The role of PAI teachers in the development of students' morals is very important in order to foster students to become students who have noble character and character. Along with the development of the times, the school has now begun to experience many changes ranging from student morals, religion, discipline, and to daily discipline. One of these objectives is to determine the planning of PAI teachers in the formation of students' morals at SMA X Cimahi. This study uses a qualitative approach using descriptive methods, the data obtained through two types, namely primary data and secondary data. In this study, data were collected through interviews, observation and documentation studies. The results of this study PAI teachers play an important role in fostering students to become students who have noble character and character by instilling honesty, disciplined behavior, self-confidence, caring, independent, persistent and responsible attitudes. Factors that influence the role of PAI teachers in providing moral guidance to students.
\end{abstract}

Keywords: Guidance and Counseling, Morals, the Role of the Teacher

Abstrak. Bimbingan Konseling adalah proses pemberian bantuan yang dilakukan melalui wawancara konseling (face to face) oleh seorang ahli (disebut konselor) kepada individu yang sedang mengalami masalah (disebut konseli) bermuara pada teratasinya masalah yang dihadapi konseli. Akhlak ialah suatu sifat yang tertanam dalam jiwa setiap manusia yang menimbulkan macam-macam perbuatan dengan secara gamblang dan mudah, tanpa memerlukan pemikiran dan pertimbangan. Peran guru PAI pada perkembangan ahklak siswa sangat berperan penting agar membina anak didik menjadi siswa yang berakhlak mulia dan berbudi pekerti. Seiring berkembangnya zaman, sekolah tersebut kini sudah mulai mengalami banyak perubahan mulai dari akhlak siswa, agama, tata tertib, dan terhadap kedisiplinan sehari-hari. Salah satu dari tujuann ini untuk mengetahui perencanaan guru PAI dalam pembentukan akhlak siswa di SMA X Cimahi, Penelitian ini menggunakan pendekatan kualitatif dengan menggunakan metode deskriptif, data yang diperoleh melalui dua jenis yaitu data primer dan data sekunder. Dalam penelitian ini data yang dikumpulkan melalui wawancara, observasi dan studi dokumentasi. Hasil penelitian ini Guru PAI berperan penting dalam membina peserta didik menjadi siswa yang berakhlak mulia dan berbudi pekerti dengan menanankam sifat jujur, perilaku disiplin, rasa percaya diri, sikap peduli, mandiri, gigih dan tanggung jawab. Faktor yang mempengaruhi peran guru PAI memberikan bimbingan akhlak pada siswa

Kata Kunci: Bimbingan dan konseling, Akhlak, Peran Guru. 


\section{A. Pendahuluan}

\section{Latar Belakang}

Secara umum tujuan dari layanan bimbingan dan konseling adalah sesuai dengan tujuan pendidikan nasional, sebagaimana tertuang dalam Undang-undang Sistem Pendidikan Nasional No. 20 Tahun 2003, yaitu untuk mengembangkan potensi peserta didik agar menjadi manusia yang beriman dan bertakwa kepada Tuhan Yang Maha Esa, berakhlak mulia, sehat berilmu, cakap, kreatif, mandiri dan menjadi warga negara yang demokratis serta bertanggung jawab. Sedangkan tujuan khusus dari bimbingan dan konseling adalah untuk membantu siswa agar dapat mencapai tujuan-tujuan perkembangan yang meliputi aspek pribadi, sosial, belajar, karir. (Erhamwilda. $2015: 20$ )

Masa remaja ialah suatu masa peralihan antara masa anak dan masa dewasa. Pada dasarnya mereka bukanlah anak-anak, baik bentuk badan ataupun cara berfikir atau bertindak tetapi bukan pula orang dewasa yang telah matang. Pada masa itu pula proses pencarian jati diri dimulai. Dalam ukuran dunia pendidikan, umumnya usia remaja berada di jenjang SMP dan SMA atau sederajat. Fenomena yang terkenal belakangan ini adalah mengenai perilaku kepada guru, tawuran antar pelajar dan lain sebagainya. Hal ini di sebabkan adanya berbagai faktor seperti lingkungan individual, kurangnya dalam keharmonisan hubungan anggota keluarga, tayangan televisi, tokoh-tokoh idola, internet. Oleh karena itu sekolah berperan penting untuk mengatasi permasalahan tersebut dan di sinilah peran guru PAI dalam bimbingan dan konseling untuk membantu dalam memperbaiki akhlak para siswa

Pendidikan sendiri berusaha menghasilkan tujuan-tujuan positif dalam diri peserta didik yang sedang berkembang untuk menuju kedewasaan. Bimbingan merupakan bantuan kepada suatu individu dalam menghadapi persoalan-persoalan yang dapat timbul dalam diri peserta didik pada kehidupannya. Bantuan ini sangat diperlukan di sekolah, agar setiap peserta didik dapat mencapai perkembangan diri dalam berakhlakul karimah.

Akhlak yang baik bagi umat muslim ialah menjadikan sarana untuk dapat menjadi sosok pribadi muslim yang sejati yang berakhlakul karimah dan sarana untuk dapat mendekatkan diri kepada Allah SWT. Seorang muslim mengerjakan itu semua bukan karena didasari atas ingin mendapat pujian dan kebanggaan atau mencari pamrih, tetapi hanya untuk mendaapatkan ridha dari Allah. Akhlak mulia ialah suatu perbutan baik atau amal kebajikan yang sangat diharapkan manusia salah satu untuk bekalan ke negeri akhirat nanti. Namun untuk dapat memiliki akhlakul karimah perlu adanya tindakan bimbingan yang secara khusus yang dilakukan oleh seseorang. Dengan cara melalui pendidikan agama atau pendidikan akhlak. Hal inilah yang dijadikan alasan oleh saya untuk lebih memfokuskan pada pembahasan ini hanya pada pendidikan agama dan akhlak siswa. Perlu dijelaskan dalam judul penelitian yang saya ambil ini adalah tentang peran guru PAI, bimbingan dan konseling, dan perkembangan akhlak.

Berdasarkan hasil penelitian yang saya lakukan maka hal ini bahwa di sekolah tersebut terdapat permasalahan yang muncul di sekolah SMA Paundan 2 Cimahi ialah tentang akhlak siswa pada umunya yang terletak pada kurangnya pembinaan dalam hal beribadah, pengajaran agama Islam, kedisiplinan di sekolah, sikap terhadap guru dan teman. Maka untuk mengurangi permaslahan tersebut pada siswa ini perlu mendapat pantauan.

Melihat dari kenyataan yang terdapat di lapangan seperti itu, maka untuk itu saya tertarik untuk mengadakan observasi dan penelitian tentang peran guru PAI dalam Bimbingan dan Konseling upaya untuk membantu dalam pembentukkan akhlak siswa yang baik, mengarahkan dan membina terhadap Akhlak siswa di sekolah SMA X Kota Cimahi dengan berjudul "Peran Guru PAI dalam Bimbingan dan Konseling terhadap Perkembangan Akhlak Siswa di SMA X Kota Cimahi".

\section{Rumusan Masalah}

1. Bagaimana perencanaan guru PAI dalam pembentukan akhlak siswa di SMA X Cimahi?

2. Bagaimana proses guru bimbingan dan konseling terhadap perkembangan akhlak siswa di SMA X Cimahi?

3. Bgaiamana evaluasi guru PAI terhadap perkembangan akhlak siswa?

4. Bagaimana peran guru PAI dalam bimbingan dan konseling terhadap akhlak siswa di 


\section{SMA X Cimahi?}

\section{Tujuan Penelitian}

1. Mengetahui perencanaan guru PAI dalam pembentukan akhlak siswa di SMA X Cimahi.

2. Mengetahui proses guru bimbingan dan konseling terhadap perkembangan akhlak siswa di SMA X Cimahi.

3. Mengetahui cara evaluasi guru PAI terhadap perkembangan akhlak siswa.

4. Mengetahui peran guru PAI dalam bimbingan dan konseling terhadap akhlak siswa di SMA X Cimahi.

\section{B. Metodologi Penelitian}

Penelitian ini menggunakan pendekatan kualitatif yang merupakan sebuah penelitian daalam betuk kata-kata dan bahasa dengan memanfaatkan berbagai metode berdasarkan prilaku yang diamati. Penelitian kualitatif pada dasarnya landasan teoritisnya bertumpu secara mendasar pada fenomenologi dan menggali makna dalam penelitian. Oleh karena itu, pada bagian ini fenomenologi dijadikan sebagai dasar teoritis utama sedang yang lainnya yaitu interaksi simbolik, kebudayaan, dan etnometodologi dijadikan sebagai dasar tambahan yang melatarbelakangi secara teoritis penelitian kualitatif. Metode yang digunakan dalam penelitian ini yaitu metode deskriptif. Teknik-teknik dalam pengumpulan data yang digunakan yaitu sebagai berikut:

1. Wawancara

Wawancara diguakan untuk mendapatkan data wawancara kepada kepala sekolah, waka kurikulum, guru, serta siswa di SMA X Cimahi.

Teknik wawancara dilakukan dari bulan Agustus s.d. September 2020, dengan teknik wawancara terbuka dan tidak terstruktur artinya dilakukan pendalaman terhadap jawaban yang dihasilkan. Digunakannya wawancara tidak terstruktur dalam penelitian ini disebabkan adanya beberapa kelebihan, yaitu dapat dilakukan secara lebih personal yang memungkinkan perolehan informasi sebanyak-banyaknya.

Pendekatan wawancara dalam penelitian ini kadang-kadang dilakukan berdasarkan perjanjian atau spontan sesuai dengan peluang waktu yang diberikan oleh informan. Apabila diperkenankan informan dan diperlukan oleh peneliti, maka selama berlangsungnya wawancara digunakan buku pencatat, mesin perekam (tape recorder), dan pengambilan foto dengan digital kamera.

2. Observasi

Observasi dalam penelitian ini adalah observasi partisipatif, di mana peneliti dalam pengamatan ikut melakukan kegiatan yang dilakukan narasumber. Observasi partisipan yang dilakukan dalam penelitian ini terbagi tiga tahapan observasi, dimulai dari observasi deskriptif (descriptive observations) secara luas dengan melukiskan secara umum situasi sosial yang terjadi di SMA X Cimahi sebagai setting penelitian.

3. Studi Dokumentasi

Teknik Studi dokumentasi dimaksudkan untuk memperoleh data yang bersifat dokumenter yang ada di lapangan seperti: data yang terdapat di SMA X Cimahi yang menjadi lokasi penelitian. Data dokumentasi.

berupa foto,data sekolah, data kegiatan, data arsip-arsip di SMA X Cimahi. Untuk menjadi sumber data yang kuat bagi penelitian terhadap data dokumenter.

\section{Hasil Penelitian dan Pembahasan}

\section{Perencanaan guru PAI dalam pembentukan akhlak siswa di SMA X Cimahi}

Pada perencanaan ini selain al-Qur'an dan hadist, yang menjadi dasar dilaksananya pembentukan akhlak di SMA X Kota Cimahi adalah Undang-undang Sisdiknas Nomor 20 Tahun 2003 Pasal 3.2 Dalam pasal tersebut telah dijelaskan bahwa salah satu tujuan Pendidikan adalah "Pendidikan nasional berfungsi mengembangkan kemampuan dan membentuk watak serta peradaban bangsa yang bermartabat dalam rangka mencerdaskan kehidupan bangsa, 
bertujuan untuk berkembangnya suatu potensi pada peserta didik agar menjadi manusia yang beriman dan bertakwa kepada Tuhan Yang Maha Esa, berakhlak mulia, sehat, berilmu, cakap, kreatif, mandiri dan menjadi warga negara yang demokratis serta bertanggung jawab".

\section{Proses guru PAI dan bimbingan konseling terhadap perkembangan akhlak siswa di SMA} X Cimahi

Proses bimbingan dan konseling yang terjadi di SMA X Kota Cimahi tidak terlepas dari penggunaan media dan penerapan metode terbaik yang diterapkan oleh guru PAI SMA X Kota Cimahi.

Metode yang digunakan ini merupakan suatu cara atau upaya yang dilakukan oleh pendidik agar prosespembentukan siswa sesuai dengan tujuan yang diharapkan. Peran guru PAI dalam membentukan akhlak siswa SMA X Kota Cimahi dilakukan dengan menggunakan metode pembiasaan dan keteladanan. Menurut kepala Sekolah Metode pembiasaan dilaksanakan melalui program yang telah ditetapkan oleh SMA X Kota Cimahi, yakni terdapat pada program rutinitas harian dan incidental contoh seperti mengucapkan salam dan menyapa guru-guru setiap kali bertemu, sholat sunnah dhuha, sholat dhuhur berjamaah, dan sebagainya.

\section{Pelaksanaan Evaluasi guru PAI terhadap perkembangan akhlak siswa}

Evaluasi berikutnya adalah evaluasi yang dilakukan oleh pendidik dan peneliti. Evaluasi ini memerlukan waktu selama berbulan lamanya. Untuk memperkuat hasil yang didapatkan proses evaluasi ini dibantu dengan penilaian teman sebaya dan hasil wawancara kepada masyarakat lingkungan peserta didik kelas X di SMA X Kota Cimahi.

Peran guru PAI dalam bimbingan dan konseling terhadap akhlak siswa di SMA X Cimahi Hasil Peran guru PAI dalam membentuk akhlak siswa di SMA X Kota Cimahi Hasil pembentukan akhlak siswa bisa lihat dari perubahan sikap dan tingkah laku yang dialami siswa selama masa Pendidikan di SMA X Kota Cimahi. Memang susah untuk mengidentifikasikan perubahan sikap dan tingkah laku tersebut sehingga dapat dikatakan sebagai akhlak karimah.

\section{Kesimpulan}

Pembentukan akhlak siswa tidak hanya mencakup sebagian mata pelajaran PAI. Akan tetapi terintegrasikan pada semua pelajaran umum dan kegiatan ekstra kurikuler selain dari program pembentukan yang dilaksanakan.

Hasil yang diharapkan dari pembentukan akhlak siswa di SMA X Kota Cimahi adalah terbentuknya siswa yang berakhlak karimah dan bisa menjadi penerus bangsa dengan memiliki kualitas yang baik. Meskipun susah untuk mengidentifikasi perubahan sikap sehingga bisa dikatakan akhlak mulia, akan tetapi perubahan sikap dari siswa di SMA X Kota Cimahi bisa dilihat dari keseharian mereka selama berpendidikan di Lembaga Pendidikan ini.

Tidak hanya pendidik yang bertanggung jawab atas keberhasilan dari pembentukan akhlak siswa, akan tetapi juga menjadi tanggung jawab orang tua dengan guru dalam hal membentuk akhlak siswa agar hasil yang dicapai bisa maksimal.

\section{Acknowledge}

Terimakasih saya ucapkan kepada:

1. Kepada Dekan Fakultas Tarbiyah dan Keguruan UNISBA, Bapak Enoh Nuroni, Drs., M.Ag.

2. Kepada kepala program studi Pendidikan Agama Islam bapak Aep Saepudin, M.Ag

3. Kepada Dosen Wali, Bapak Adang M. Tsaury, Drs., M.Pd.I. dan Bapak Eko Surbiantoro, Drs., M.Pd.I

4. Kepada Dosen Pembimbing Ibu Erhamwilda, Dra., M.Pd.

\section{Daftar Pustaka}

[1] Ahmadi, Abu. 1991. Psikologi umum. Surabaya : Bina Ilmu.

[2] Ahmad Tafsir. 2012. Ilmu Pendidikan Islam. Bandung: Remaja Rosdakarya 
[3] Beni Ahmad Saebani, dan Abdul Hamid. 2017. Ilmu Akhlak. Bandung: Pustaka Cipta

[4] Darajat Zakiyah. 1996. Metodologi Pengajaran Agama Islam. Jakarta: Bumi Aksara.

[5] Erhamwilda.2015. Konseling Sebaya Alternatif Bimbingan Konseling di Sekolah. Yogyakarta :Media Akademik

[6] Ihsan Hamdan dan A. Fuad Ihsan. 2001. Filsaafat Pendidikan Islam. Bandung: Pustaka Setia

[7] Kamaludin, Bimbingan Konseling di Sekolah, (Universitas Muhamadiyah HAMKA: Jurnal Pendidikan dan Kebudayaan:2014)

[8] Moleong, Lexy J. 2007. Metodologi Penelitian Kualitatif. Bandung : PT. Remaja Rosdakarya.

[9] Prayitno. 2004. Dasar-dasar Bimbingan Konseling. Jakarta: Rineka Cipta.

[10] Prayitno. 2011. Panduan Kegiatan Pengawasan Bimbingan Konseling di Sekolah,. Jakarta: Rineka Cipta.

[11] Sugiyono. 2012. Metode Penelitian Kuantitatif Kualitatif dan R\&D. Bandung: Alfabeta

[12] Syamsu Yusuf. 2000. Psikologi Perkembangan Anak. Bandung: Rosdakarya.

[13] W.J.S. Purwadarminta. 2003. Kamus Umum Bahasa Indonesia. Jakarta:Balai Pustaka 